\title{
WOOD VOLUMETRY OF Tachigali vulgaris PURE PLANTATIONS IN DIFFERENT PLANTING SPACINGS
}

\author{
Larissa de Oliveira Ramos ${ }^{1 *}$, Rodrigo Otávio Veiga de Miranda ${ }^{2}$, Alvaro Augusto Vieira Soares ${ }^{3}$, Thiago de \\ Paula Protásio ${ }^{4}$, Delman de Almeida Gonçalves ${ }^{5}$
}

${ }^{1 *}$ Midwest State University, Postgraduate Program in Forestry Science, Irati, Paraná, Brazil - *ramoslarissa212@gmail.com ${ }^{2}$ Federal University of Uberlândia, Institute of Agrarian Sciences, Monte Carmelo, Minas Gerais, Brazil - rovmiranda@gmail.com ${ }^{3}$ Federal University of Uberlândia Institute of Agrarian Sciences, Monte Carmelo, Minas Gerais, Brazil - alvaroavsoares@gmail.com ${ }^{4}$ Federal Rural University of Amazônia, Department of Forest Engineering, Parauapebas, Pará, Brazil - depaulaprotasio@ gmail.com ${ }_{5}^{5}$ Oriental Amazonian Embrapa, Belém, Pará, Brazil - delmangoncalves@gmail.com

Received for publication: 10/07/2020 - Accepted for publication: 25/10/2020

\begin{abstract}
Resumo
Volumetria em povoamentos de tachi-branco (Tachigali vulgaris) em diferentes espaçamentos. Este trabalho objetivou desenvolver equações volumétricas para árvores de tachi-branco (Tachigali vulgaris L. G. Silva \& H. C. Lima), avaliando o efeito do espaçamento inicial de plantio nas estimativas de volume, assim como desenvolver uma equação para estimativa do diâmetro equivalente $\left(\mathrm{d}_{\mathrm{eq}}\right)$. Os dados são provenientes de um experimento implantado no norte do estado do Pará. O experimento foi conduzido sob o delineamento em blocos casualizados, sendo três blocos, cada um com seis tratamentos. Modelos volumétricos mais comumente utilizados foram avaliados, para duas situações distintas: considerando cada fuste como uma árvore e utilizando o deq da árvore como variáveis independentes no modelo volumétrico. A necessidade de equações individuais por espaçamento inicial de plantio foi testada. Além disso, uma equação para estimativa do $d_{\mathrm{eq}}$ foi proposta. $\mathrm{O}$ uso do $\mathrm{d}_{\mathrm{eq}}$ promoveu estimativas volumétricas mais precisas e acuradas em relação ao diâmetro à altura do peito. Dentre os modelos testados, o de Schumacher e Hall foi selecionado. Pelo teste de identidade de modelos, a equação $\mathrm{v}=\mathrm{e}^{\left(-9,164635+1,912123 \operatorname{Ln}\left[d_{\mathrm{eq}}\right]+0,751405 \operatorname{Ln}[h]\right)}$ pode ser utilizada para estimar o volume de árvores de Tachigali vulgaris, independente do espaçamento de plantio. $\mathrm{O} \mathrm{d}_{\text {eq }}$ pode ser estimado via equação a partir dos diâmetros máximos e mínimos dos fustes da árvore. As diferenças percentuais máximas de volume por hectare obtidos pela medição de todos os fustes e pelo $\mathrm{d}_{\mathrm{eq}}$ foram apenas de $5 \%$, não causando prejuízo na acurácia da produção por unidade de área.

Palavras-chave: florestas energéticas, produção volumétrica, densidade de plantio, carvoeiro.
\end{abstract}

Abstract
The aim of this study was to develop volumetric equations for tachi-branco trees (Tachigali vulgaris L. G. Silva
$\&$ H. C. Lima), by assessing the effect of initial planting spacing in volume estimates, as well as developing an
equation to estimate the equivalent diameter $\left(\mathrm{d}_{\mathrm{eq}}\right.$ ). Data are from an experiment located in north Pará. The
experiment was conducted with the randomized blocks design, being three blocks with six treatments each. The
most used volumetric models were assessed for two distinct situations: considering each trunk as a tree and
using the tree $\mathrm{d}_{\mathrm{eq}}$ as independent variables in the volumetric model. The need for individual equations for initial
planting spacing was tested. In addition, an equation for $\mathrm{d}_{\mathrm{eq}}$ estimate was proposed. The use of deq provided
more precise and accurate volumetric estimates regarding diameter at breast height. Among the models tested,
the Schumacher-Hall model was selected. Through the model identity test, the equation
$\mathrm{v}=\mathrm{e}\left(-9.164635+1.912123 \mathrm{Ln}\left[\mathrm{d}_{\mathrm{eq}}\right]+0.751405 \mathrm{Ln}[\mathrm{h}]\right)$ can be used to estimate tree volume of Tachigali vulgaris,
regardless of planting spacing. The equivalent diameter can be estimated via equation from minimum and
maximum diameters of tree trunks. The maximum percentage differences of volume by hectare obtained with
the measurement of all trunks and $\mathrm{d}_{\mathrm{eq}}$ were only $5 \%$ without loss in production accuracy per unit of area.
Keywords: energetic forests, volumetric production, planting density, collier.

\section{INTRODUCTION}

Brazil is a country with an outstanding forestry-suitable land. The current estimate of planted area is 9 million hectares, mainly represented by species of Eucalyptus and Pinus (IBÁ, 2020). However, there are other species with potential commercial use such as tachi-branco (Tachigali vulgaris L.G.Silva \& H.C.Lima). Tachi-branco is an arboreous leguminous species which occurs generally in north and central-west Brazil, especially Pará and Amazonas. In full sun conditions, its growth is relatively fast, with annual increments of diameter and height of $3.4 \mathrm{~cm}$ and $2.5 \mathrm{~m}$, respectively, and diameter at breast height can reach 70 to $100 \mathrm{~cm}(1.30 \mathrm{~m}$ above ground $)$ and 20 to $30 \mathrm{~m}$ height in adult trees (CARVALHO, 2005).

It is a recommended species for arborization of parks and motorways, recovery of degraded areas (FARIAS et al., 2016), and for energy purposes (ORELLANA et al., 2018; SILVA et al., 2019). Recent studies have indicated that its wood is resistant to certain fungi such as Postia placenta (STALLBAUN et al., 2016). Moreover, it has a great potential for finer timber use and as a compound to be grinded and mixed to cement in the construction industry (SOUSA et al., 2016). 
Although the species has promising silvicultural characteristics, studies about its management and silviculture are still scarce. Thus, conducting research with this species is necessary in order to develop silvicultural prescriptions and optimal management systems for its production (ELOY et al., 2014). An important characteristic to be studied for the development of silviculture and management of a forest species is the production under different environmental and management conditions. As volume is the unit frequently used to represent the amount of wood, the volumetric study is essential for decision-making regarding forest management of a species (MACHADO et al., 2002).

The most common way to estimate tree volume in a forest stand is using equations based on volumetric models (PELISSARI et al., 2011). Thus, it is vital that equations are developed in a way to generate estimates with the precision and accuracy demanded for such purpose. There is a lack of studies about volumetry for tachi-branco, especially those that contemplate different planting spaces. Some characteristics must be considered to develop volume equations, especially those that can influence on the shape and volume of trees.

One of these characteristics is planting spacing, which has effect on timber production per tree, and affects dendrometric attributes that influence volume (MOULIN et al., 2017; SILVA et al., 2019). Therefore, it is essential to assess the need to develop independent equations for each planting spacing, aiming to ascertain whether the specificity of adjustments contributes significantly to error reduction, comparatively to the adjustment of a single model using all available data.

A common feature shown by tachi-branco trees in stands is trunk forking, which results in trees with two or more trunks (ROLIM; PIOTTO, 2018). The volume of forked trees is usually estimated considering each trunk as an individual tree. In these cases, an alternative to obtain volumetric estimates directly for the tree is the use of equivalent diameter $\left(\mathrm{d}_{\mathrm{eq}}\right)$ as an independent variable to replace trunk diameter. Equivalent diameter $\left(\mathrm{d}_{\mathrm{eq}}\right)$ represents the diameter at $1.30 \mathrm{~m}$ referring to the transversal area of a tree with multiple trunks, obtained by the sum of individual transversal areas of each trunk. For this purpose, it is relevant to consider alternatives to obtain $d_{\mathrm{eq}}$ estimates.

Based on these considerations, the aim of this study was: i) to develop volumetric equations for tachibranco plantings; ii) to develop an equation for the prediction of equivalent diameter aiming to increase the pace of measurements, without the need to measure all trunks of forked trees. Three hypotheses were assessed: $h_{0(1)}=$ volume estimates obtained with equations adjusted by spacing are more precise and accurate than those obtained with a single equation developed for all data; $h_{0(2)}=$ equivalent diameter is an alternative to the use of diameter at breast height as an independent variable in the volumetric model for forked trees; $h_{0(3)}=$ the volume per area unit obtained considering the estimated equivalent diameter does not statistically differ from the respective volume obtained considering observed equivalent diameter.

\section{MATERIAL AND METHODS}

Data was obtained from an experiment on initial planting spacing of tachi-branco (Tachigali vulgaris L. G. Silva \& H. C. Lima) developed in 2010 in Monte Dourado, a district of the municipality of Almeirim, north Pará, through a partnership between the Brazilian Agricultural Research Corporation (EMBRAPA) and the company Jari Celulose S/A. According to the Köppen-Geiger classification, the climate is Aw, with mean temperature $26.3^{\circ} \mathrm{C}$ and mean annual rainfall 1,654 mm (CLIMATE-DATA.ORG, 2021).

The experiment was set up as randomized blocks design (RBD), being three blocks with six treatments each. The tested treatments had the following initial planting spacings: $3.0 \times 1.5 \mathrm{~m} ; 3.0 \times 2.0 \mathrm{~m} ; 3.0 \times 2.5 \mathrm{~m} ; 3.0$ $\times 3.0 \mathrm{~m} ; 3.0 \times 3.5 \mathrm{~m}$; and $3.0 \times 4.0 \mathrm{~m}$. The experimental plots of all treatments were installed measuring $3,060 \mathrm{~m}^{2}$ $(51 \times 60 \mathrm{~m})$, and only the 49 central plants represented the plot usable area while the remaining were considered borders. Plots were continuously inventoried at planting ages 35.97, 45.07, 57.27, 68.84, 91.56; and 103.43 months. Diameter at breast height (d) and total height (h) of all trees (forked or not) were measured in each plot.

Three trees per treatment in each block were measured at ages 87 and 102 months, aiming to include the largest diametric variation possible, in a total of 107 trees, as after the exploratory data analysis one tree had to be removed due to inconsistent volume. The rigorous tree measurement was conducted in an absolute way by measuring trunk diameter at felling height, at 0.70,1.30, $2.00 \mathrm{~m}$ above ground, and subsequently from 2.00 to 2.00 $\mathrm{m}$, up to the commercial tree height. Volumes of trunk segments were obtained with the Smalian formula. The sum of segments' volumes up to the commercial height resulted in the commercial value of trunks with bark. Commercial height was that corresponding to the $15 \mathrm{~cm}$ circumference, with the limit being established by the timber company.

Volumetric models were adjusted by considering two situations established by tree forking. In situation 1 , the dependent variable was the commercial value with bark by trunk, each considering an individual tree. In this case, the dependent variables in the model were diameter at breast height (d) and total trunk height (h). In situation 2 , commercial value with bark was the dependent variable. This volume represented the sum of commercial values 
with bark of each tree trunk. For this purpose, the use of equivalent diameter $\left(\mathrm{d}_{\mathrm{eq}}\right)$ was needed for forked trees (SILVA et al., 2018; DOMBROSKI; PINTO, 2019). This diameter was obtained by the square root of the sum of each squared diameter at breast height of tree trunks, representing the equivalent diameter to a given segmental area (CAMPOS \& LEITE, 2017). The expression is given by $d_{e q_{j}}=\sqrt{\sum_{i=1}^{n} d_{i}^{2}}$, where $\mathrm{d}_{\mathrm{eq}}$ corresponds to equivalent diameter of the $j$-th tree $(\mathrm{cm})$, measured at $1.30 \mathrm{~m}$ above ground; $n$ is the number of trunks of the $j$-th tree. In this situation, the height of forked trees corresponded to that of the highest trunk.

The most used volumetric models found in the relevant literature were assessed. Three simple entry models (Hohenadl-Krenm, Brenac and Husch) and four double entry models (Spurr, Schumacher-Hall, Stoate and Naslund) were tested (GAMA et al., 2015).

Initially, the models were adjusted for the total of data not considering the difference of treatments. From these adjustments, the model with the best equation was individually adjusted for each treatment. The adjustment was carried out with the ordinary least squares method. The significance of equations was assessed with the $F$ test and the significance of coefficients with the " $t$ " test, both with 5\% significance level. For the determination of the non-significant coefficient, the associated variable was not considered and the model was readjusted.

The statistics to assess model adjustment were adjusted coefficient of determination $\left(\mathrm{R}^{2}\right.$ aj $)$ and relative standard error of estimate $\left(\mathrm{S}_{\mathrm{yx}} \%\right)$, both calculated for the variable of interest, graphic analysis of percentage residuals (Res\%), and the dispersion between observed and estimated volumes. For the equations whose dependent variable underwent logarithmic transformation, the logarithmic discrepancy correction factor of Meyer (FCMeyer) was calculated. This factor was included in the $\beta_{0}$ coefficient of the equation. The expressions used in the calculation of statistics were $R_{a j}^{2}=1-\left(\frac{n-1}{n-p}\right)\left(\frac{\sum_{i=1}^{n}\left(y_{i-} \hat{y}_{i}\right)^{2}}{\sum_{i=1}^{n}\left(y_{i-} \bar{y}\right)^{2}}\right) ; S_{y x} \%=100 \sqrt{\frac{\sum_{i=1}^{n}\left(y_{i-} \hat{y}_{i}\right)}{n-p}} \bar{y}^{-1} ; \operatorname{Res} \%=100\left(y_{i}-\right.$ $\left.\hat{y}_{i}\right) y_{i}^{-1} ; F C_{\text {Meyer }}=e^{\left(0.5 s_{y x^{2}}\right)}$, where $\mathrm{n}$ is the number of observations, $\mathrm{p}$ is the number of parameters, $y_{i}$ and $\hat{y}_{i}$ are the observed and estimated volume values, respectively, $\bar{y}$ is the average commercial value with bark.

The model identity test (TIM) was used (REGAZZI; SILVA, 2010) to verify the following hypotheses: $\mathrm{h}_{0}$ : a single equation can be used to estimate tree volume regardless of planting spacing; $\mathrm{h}_{1}$ : it is necessary to develop an independent equation for at least one initial planting spacing. Subsequently, the behavior of volumetric estimates in the different planting spacings was analysed. For this purpose, simulated values of equivalent diameter and total height were used, compatible with the variation of observed data.

In order to optimize the measurement time of diameter of forked trees, an equation to estimate $\mathrm{d}_{\mathrm{eq}}$ was proposed. To that end, the equation was assessed assuming $\mathrm{d}_{\mathrm{eq}}$ and $\mathrm{Ln}\left(\mathrm{d}_{\mathrm{eq}}\right)$ as dependent variables. As independent variables, the number of trunks of each tree, minimum and maximum diameters among tree trunks and respective transformations $\left(\mathrm{x}^{2}, \mathrm{x}^{3}, \mathrm{x}^{-1}\right.$ e $\left.\mathrm{Ln}[\mathrm{x}]\right)$ were tested. The choice for these variables was due to their availability in the field. Trees with only one trunk were not considered in the database of these adjustments. In total, data from 2,896 trees were used.

To determine the equation to estimate $\mathrm{d}_{\mathrm{eq}}$, the variable selection process used was Forward. This method is based on the order of variables established by their importance. From an initially empty model, the variables are inserted one by one, in order of importance in modelling. If there is increase in accuracy, the variable is maintained in the equation, otherwise it is eliminated, and the next variable is added. When all variables are tested, the process is finished.

The statistics to assess the proposed equations were adjusted coefficient of determination $\left(\mathrm{R}_{\text {aj }}{ }\right)$, relative standard error of estimate $\left(\mathrm{S}_{\mathrm{yx}} \%\right)$, in addition to the dispersion of observed and estimated values of $\mathrm{d}_{\mathrm{eq}}$. A verification of the effect of estimated $\mathrm{d}_{\mathrm{eq}}$ in the volumetric production per area unit was performed. The paired " $\mathrm{t}$ " test (5\% significance) was applied to verify compatibility among volumes $\left(\mathrm{m}^{3} \mathrm{ha}^{-1}\right)$ obtained with observed and estimated $d_{\text {eq. }}$. Next, a graphic analysis for the verification of possible discrepancies in percentage was performed. The Microsoft Excel software was used for all statistical analyses.

\section{RESULTS}

In Table 1, coefficients and statistical adjustments are shown for the assessed models in the situations tested. The volumetric equations provided similar $\mathrm{R}^{2}$ aj values as well as $\mathrm{S}_{\mathrm{yx}} \%$ in the different categories and models assessed. $\mathrm{R}^{2}{ }_{\text {aj }}$ varied between 0.90 (Husch) and 0.95 (Naslund) for situation $1 . \mathrm{S}_{\mathrm{yx}} \%$ varied from $10.17 \%$ (Schumacher-Hall) to $14.21 \%$ (Husch). Significance was not observed for the $\beta_{0}$ coefficient for Stoate and Naslund models. 
Table 1. Coefficients and statistics of the models tested to estimate the commercial volume of Tachigali vulgaris in north Pará, Brazil.

Tabela 1. Coeficientes e estatísticas dos modelos testados a fim de estimar o volume comercial de Tachigali vulgaris no norte do Pará.

\begin{tabular}{|c|c|c|c|c|c|c|c|c|c|}
\hline Situation & Model & $\beta_{0}$ & $\beta_{1}$ & $\beta_{2}$ & $\beta_{3}$ & $\beta_{4}$ & $\beta_{5}$ & $\mathbf{R}^{2}$ aj & $\mathrm{S}_{\mathrm{yx}} \%$ \\
\hline \multirow{7}{*}{$1(\mathrm{~d})$} & Hohenadl-Krenm & -0.0938 & 0.0144 & 0.0002 & - & - & - & 0.92 & 12.25 \\
\hline & Brenac & -2.5129 & 0.7161 & -17.6567 & - & - & - & 0.92 & 12.21 \\
\hline & Husch & -7.6737 & 2.1872 & - & - & - & - & 0.90 & 14.21 \\
\hline & Spurr & -0.9978 & 0.9902 & - & - & - & - & 0.91 & 12.94 \\
\hline & Schumacher-Hall & -8.8260 & 2.1060 & 0.4609 & - & - & - & 0.91 & 13.36 \\
\hline & Stoate & $-0.0395^{\mathrm{ns}}$ & 0.0002 & 0.00002 & 0.0005 & - & - & 0.93 & 11.93 \\
\hline & Naslund & $0.1974^{\mathrm{ns}}$ & 0.0364 & -0.0018 & 0.0006 & -0.0001 & 0.0001 & 0.95 & 10.17 \\
\hline \multirow{7}{*}{$2\left(\mathrm{~d}_{\mathrm{eq}}\right)$} & Hohenadl-Krenm & -0.2233 & 0.0264 & $0.0006^{\mathrm{ns}}$ & - & - & - & 0.93 & 10.98 \\
\hline & Brenac & -5.1713 & 1.4911 & -9.6753 & - & - & - & 0.93 & 10.48 \\
\hline & Husch & -7.4818 & 2.1022 & - & - & - & - & 0.93 & 10.55 \\
\hline & Spurr & -9.5320 & 0.9285 & - & - & - & - & 0.95 & 9.52 \\
\hline & Schumacher-Hall & -9.1646 & 1.9121 & 0.7514 & - & - & - & 0.95 & 9.40 \\
\hline & Stoate & -0.1318 & 0.0007 & $0.00001^{\mathrm{ns}}$ & 0.0075 & - & - & 0.95 & 9.34 \\
\hline & Naslund & $0.1334^{\mathrm{ns}}$ & 0.0076 & 0.0007 & 0.0005 & $-0.00003^{\mathrm{ns}}$ & $0.0082^{\mathrm{ns}}$ & 0.95 & 9.43 \\
\hline
\end{tabular}

Where: $\mathrm{R}_{\mathrm{aj}}{ }_{\mathrm{a}}=$ adjusted coefficient of determination; $\mathrm{S}_{\mathrm{yx}} \%=$ relative standard error of estimate.

For situation 2 (use of $\mathrm{d}_{\mathrm{eq}}$ ) in a same category, statistics of quality of adjustment showed a slight oscillation. In general, $\mathrm{R}_{\mathrm{aj}}$ varied from 0.93 (simple entry models) to 0.95 (double entry models), and $\mathrm{S}_{\mathrm{yx}} \%$ varied between 9.34 (Stoate) and 10.98\% (Hohenadl-Krenm), reinforcing the superiority of models of double entry (Table 1). The Hohenadl-Krenm model showed the worst statistics. The $\beta_{0}$ coefficient of the Naslund model and $\beta_{2}$ of the Hohenadl-Krenm and Stoate models were not significant.

According to the residual dispersion of the tested models for situation 1, double entry models were higher than single entry ones. Graphs of residual dispersion and observed and estimated values of commercial value for situation 1 (use of d) for the three best double entry models are shown in Figure 1.
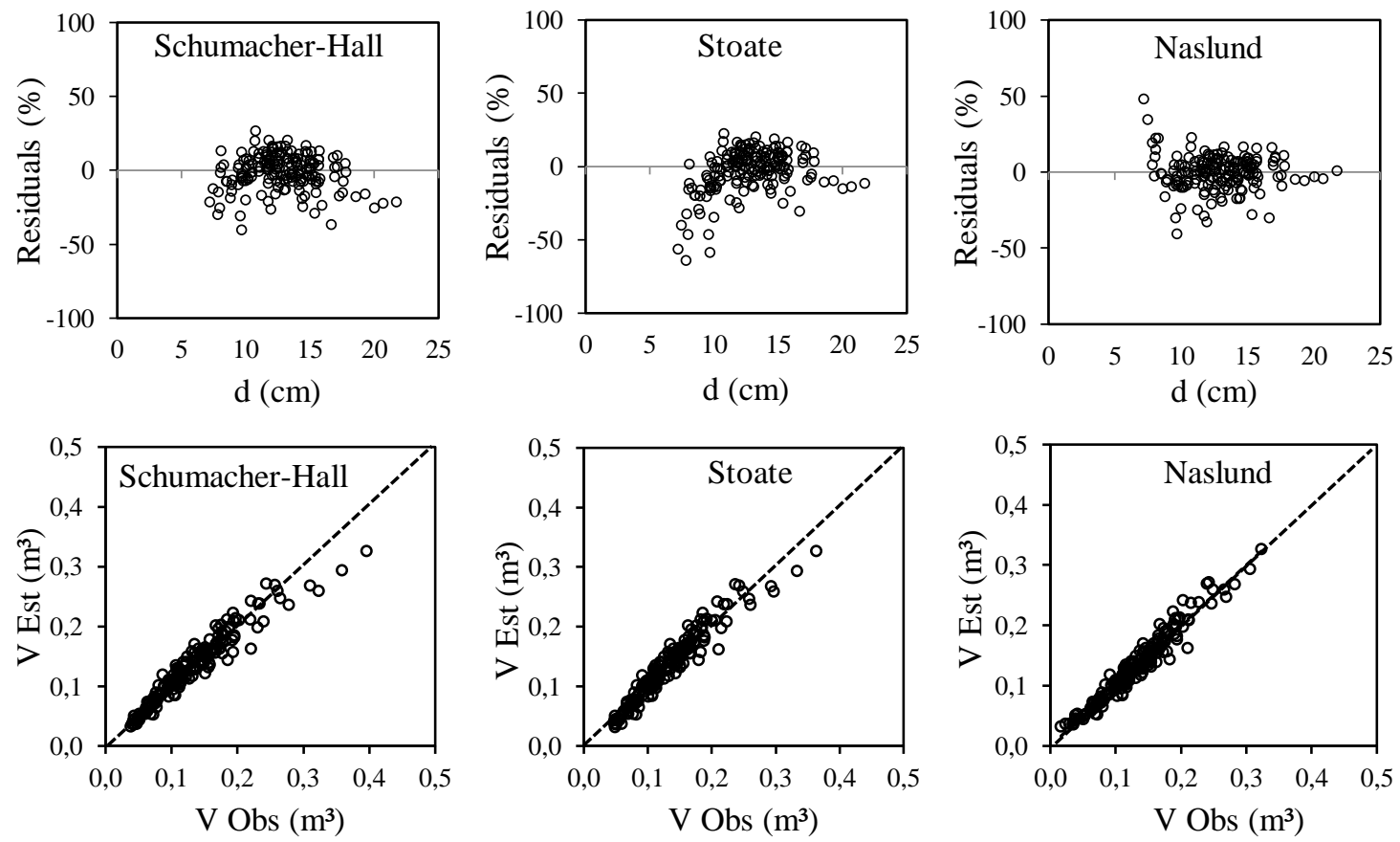

Figure 1. Residual dispersion and graphs of observed (V Obs) and estimated (V Est) values for the models tested for situation 1 (use of d), in the estimate of the commercial volume of Tachigali vulgaris in north Pará, Brazil.

Figura 1. Dispersão residual e entre os valores observados (V Obs) e estimados (V Est) para os modelos testados para a situação 1 (uso do d), na estimativa do volume comercial de Tachigali vulgaris no norte do Pará. 
The Naslund model underestimated the values of commercial volume in lower diameter classes. On the other hand, the model of Stoate overestimated volume in the diameter classes mentioned. The Schumacher-Hall model generated more accurate estimates, except for higher volumes. In all cases, dispersion occurred mainly in the range of $\pm 30 \%$ of the environment of abscissae axis (Figure 1 ).

Through the residual analysis, the Hohenadl-Krenm model was the only one that showed tendency in estimates, underestimating commercial volume for smaller size trees. Other models of the two categories tested provided tendency-free estimates. In Figure 2, the residual dispersions and of observed and estimated volumes for the three best models (double entry) are shown for situation 2 in the estimate of commercial value for Tachigali vulgaris trees in north Pará.
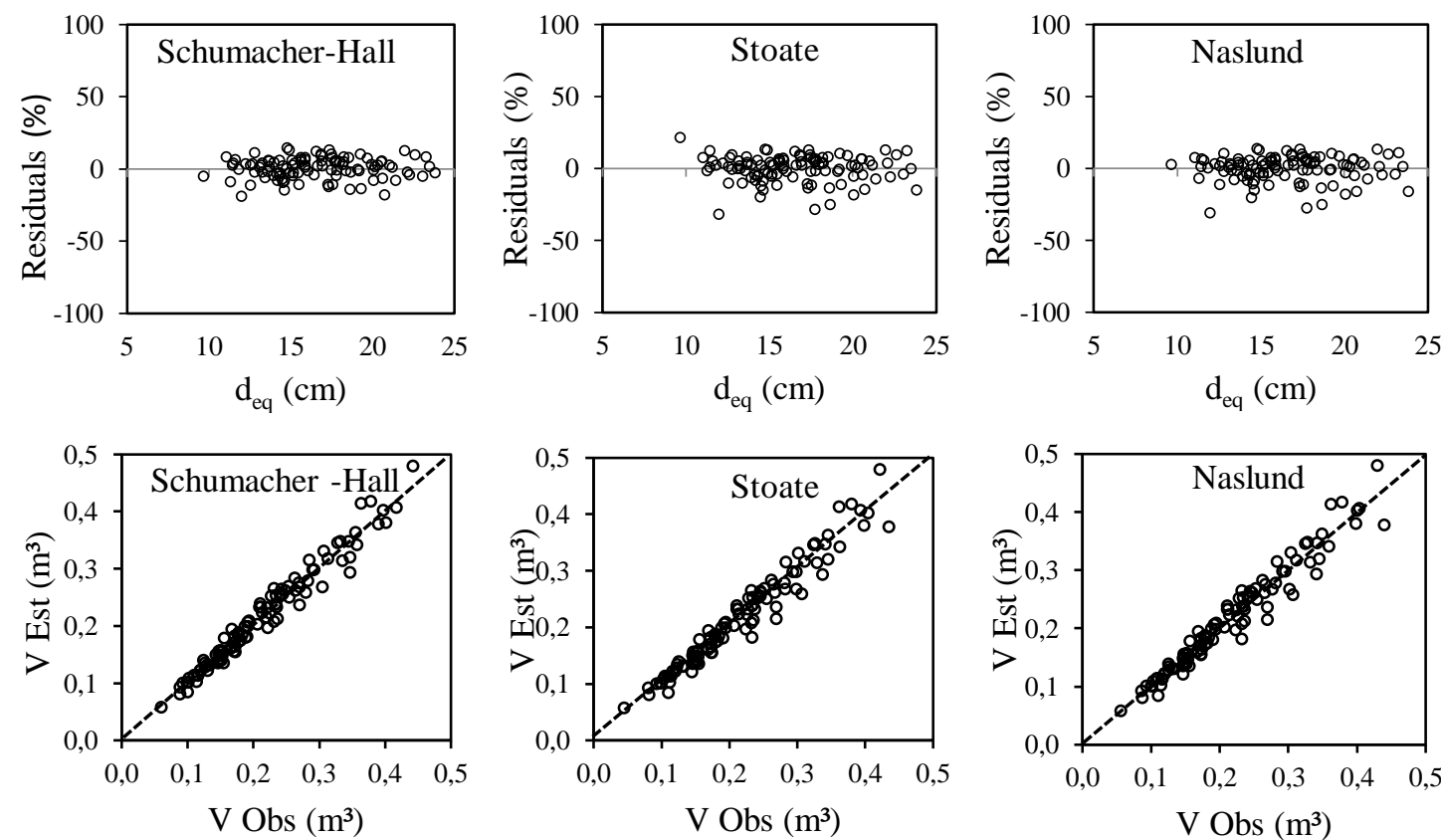

Figure 2. Residual dispersion and graphs of observed (V Obs) and estimated (V Est) values for the models tested for situation 2 (use of $\mathrm{d}_{\mathrm{eq}}$ ), in the estimate of the commercial volume of Tachigali vulgaris in north Pará, Brazil.

Figura 2. Dispersão residual e entre os valores observados (V Obs) e estimados (V Est) para os modelos testados para a situação 2 (uso do $\mathrm{d}_{\mathrm{eq}}$ ), na estimativa do volume comercial de Tachigali vulgaris no norte do Pará.

The double entry models provided accurate estimates (Figure 2), with percentage deviations closer to the horizontal axis. However, the estimates obtained with the Schumacher-Hall model occurred closer to the abscissae axis, for all the diameter range and commercial value.

In addition to all the coefficients being significant, the Schumacher-Hall model provided accurate volume estimates. Thus, this model was considered the most adequate, being tested in the database stratified by spacing. The coefficients obtained and the statistical adjustments are shown in Table 2.

Table 2. Schumacher and Hall model coefficients and statistics for situation 2 (use of $\mathrm{d}_{\mathrm{eq}}$ ) tested to estimate the volume of Tachigali vulgaris in north Pará, Brazil.

Tabela 2. Coeficientes e estatísticas do modelo de Schumacher e Hall testado para a situação 2 (uso do deq), a fim de estimar o volume de Tachigali vulgaris no norte do Pará.

\begin{tabular}{cccccc}
\hline Initial spacing $(\mathbf{m})$ & $\boldsymbol{\beta}_{\mathbf{0}}$ & $\boldsymbol{\beta}_{\mathbf{1}}$ & $\boldsymbol{\beta}_{\mathbf{2}}$ & $\mathbf{R}_{\mathbf{a j}}$ & $\mathbf{S}_{\mathbf{y x}} \boldsymbol{\%}$ \\
\hline $3.0 \times 1.5$ & -8.9758 & 1.8776 & 0.7272 & 0.90 & 11.00 \\
$3.0 \times 2.0$ & -9.6403 & 1.8790 & 0.9436 & 0.96 & 8.51 \\
$3.0 \times 2.5$ & -9.8982 & 2.1343 & 0.8035 & 0.99 & 4.52 \\
$3.0 \times 3.0$ & -9.3737 & 1.7865 & 0.9378 & 0.93 & 9.25 \\
$3.0 \times 3.5$ & -8.2072 & 2.3760 & $-0.0231^{\mathrm{ns}}$ & 0.97 & 6.70 \\
$3.0 \times 4.0$ & -8.4912 & 1.8522 & 0.5733 & 0.90 & 10.04 \\
\hline
\end{tabular}

Where: $\mathrm{R}_{\text {aj }}{ }=$ adjusted coefficient of determination; $\mathrm{S}_{\mathrm{yx}} \%=$ relative standard error of estimate. 
When using $\mathrm{d}_{\mathrm{eq}}$ only for the $3.0 \times 3.5 \mathrm{~m}$ spacing, the $\beta_{2}$ coefficient was non-significant (Table 2). The lowest values of $\mathrm{R}^{2}$ aj and the highest values of $\mathrm{S}_{\mathrm{yx}} \%$ were obtained in the extremes of spacing and in $3.0 \times 3.0 \mathrm{~m}$, as a result of the lowest correlation of the commercial value with $\mathrm{d}_{\mathrm{eq}}$ in spacings $3.0 \times 1.5 \mathrm{~m}(\mathrm{r}=0.96), 3.0 \times 3.0 \mathrm{~m}$ $(\mathrm{r}=0.95)$ and $3.0 \times 4.0 \mathrm{~m}(\mathrm{r}=0.94)$ in relation to the others. Through the residual analysis, the different treatments showed similar results, not evidencing the superiority of any specific treatment.

While testing the possibility to reduce the number of equations through the model identity test, the calculated value of statistics $F$ (1.6118) was lower than the respective tabled value (1.8045). Thus, hypothesis $h_{0}$ of this test was not rejected, assuming the possibility of using a single equation (with the same coefficients) for all spacings.

The volumes generated by the equations developed by initial planting spacing did not differ statistically from the obtained values with the adjustment of a single equation using all data available. This similarity can be an effect of the low variation in the shape of trunks between spacings, whose mean shape factor was $0.72(\mathrm{CV}=$ $4.4 \%)$. To illustrate this fact, the equations selected for each treatment and the equation developed for the total of data were used in a simulation in which the volumes were estimated from the equivalent diameters and total heights simulated according to the variation of data observed in the volume (Figure 3). Three classes of total height were adopted with varied values of $\mathrm{d}_{\mathrm{eq}}$. In addition, three classes of $\mathrm{d}_{\mathrm{eq}}$ were simulated with variations in total height.
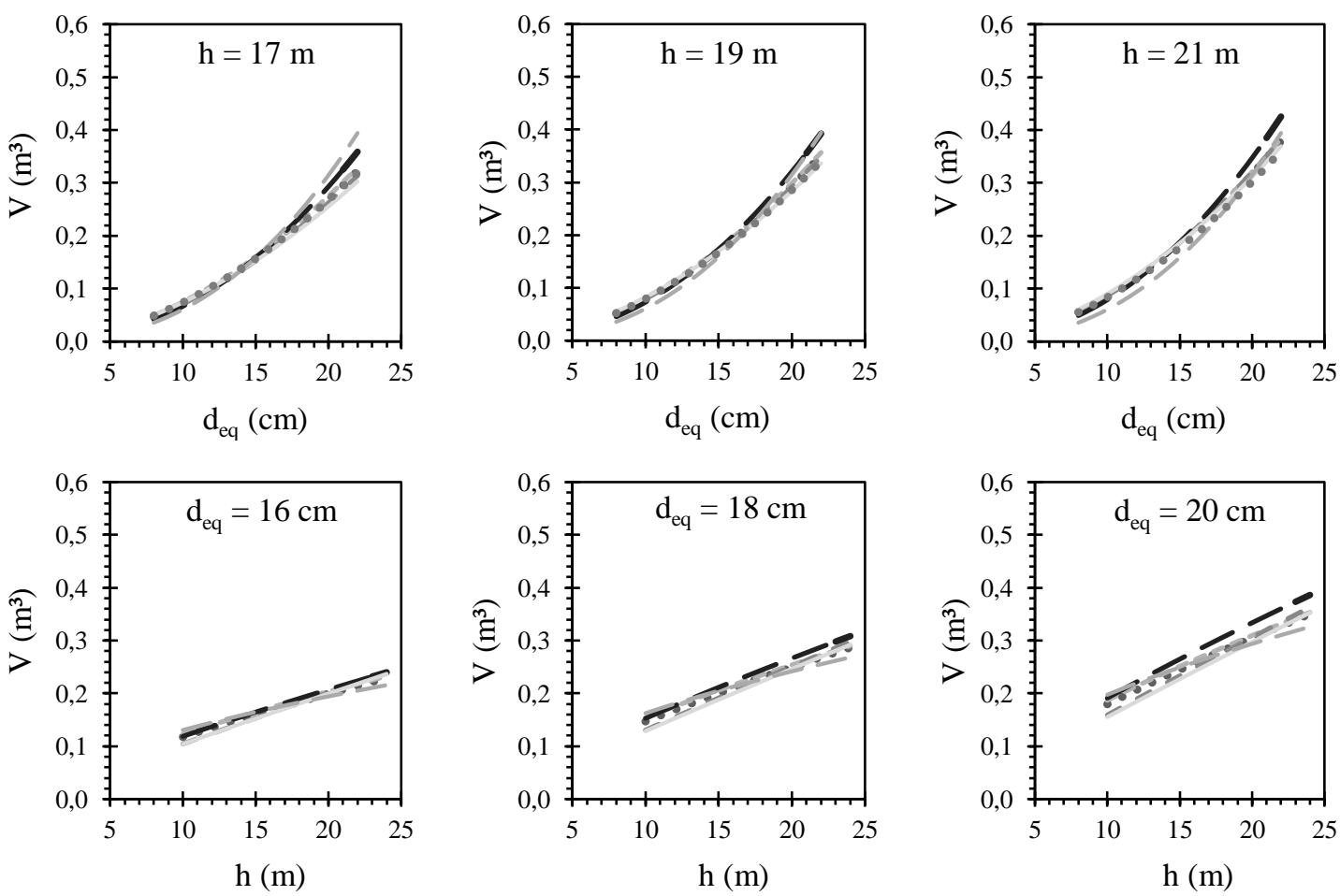

Figure 3. Behavior of the volumetric estimates generated by the general and specific equations for planting spacing, under variations of height and equivalent diameter $\left(\mathrm{d}_{\mathrm{eq}}\right)$ classes, for experimental planting of Tachigali vulgaris trees in north Pará, Brazil.

Figura 3. Comportamento das estimativas volumétricas geradas pela equação geral e específicas por espaçamento de plantio, sob variações de classes de altura e diâmetro equivalente $\left(\mathrm{d}_{\mathrm{eq}}\right)$, para árvores de plantios experimentais de Tachigali vulgaris no norte do Pará.

The highest similarity of volume was observed when classes of $d_{\text {eq }}$ were varied, indicating the lower influence of height in volumetric estimates compared to $\mathrm{d}_{\mathrm{eq}}$ (Figure 3). The highest discrepancy among estimates was observed in higher classes of $\mathrm{d}_{\mathrm{eq}}$ and in the lower classes of total height, however, with low magnitude. For instance, in a class of height $17 \mathrm{~m}$, if $\mathrm{d}_{\mathrm{eq}}$ is $15 \mathrm{~cm}$, volume can vary between 0.1528 and $0.106 \mathrm{~m}^{3}$, according to the planting spacing. Also, in a class of $\mathrm{d}_{\mathrm{eq}} 18 \mathrm{~cm}$, if the height is $20 \mathrm{~m}$, the volume for the different spacing varies between 0.2238 and $0.2665 \mathrm{~m}^{3}$.

Therefore, the equation $\mathrm{v}=\mathrm{e}^{\left(-9.164635+1.912123 \operatorname{Ln}\left[d_{\mathrm{eq}}\right]+0.751405 \operatorname{Ln}[h]\right)}$ is adequate to estimate the volume of tachi-branco trees. The next stage consisted of developing an equation to estimate equivalent diameter $\left(\mathrm{d}_{\mathrm{eq}}\right)$. The equations to estimate equivalent diameter $\left(\mathrm{d}_{\mathrm{eq}}\right)$ per tree $(\mathrm{cm})$ were 1) $\mathrm{d}_{\mathrm{eq}}=-0.561361 \mathrm{~d}_{\text {min }}+$ $1.390229 \mathrm{~d}_{\max }+2.114448 \operatorname{Ln}\left[\mathrm{d}_{\min }\right]$ and 2) $\left.\mathrm{d}_{\mathrm{eq}}=\mathrm{e}^{\left(0.006421+1.479811 \mathrm{Ln}\left[\mathrm{d}_{\max }\right]-0.091435 \mathrm{~d}_{\max }+0.001482 \mathrm{~d}^{2}{ }_{\max }+0.000018 \mathrm{~d}^{3} \min \right.}\right)$, 
where $d_{\max }$ and $d_{\min }$ are maximum and minimum diameters at breast height $(\mathrm{cm})$, respectively; and " $\mathrm{e}$ " the exponential (2.718282). Equations 1 and 2 provided the values for $\mathrm{S}_{\mathrm{yx}} \% 12.72$ and $11.53 \%$, and $\mathrm{R}^{2}$ aj 0.79 and 0.82 , respectively. When assessing the equation developed to estimate equivalent diameter $\left(\mathrm{d}_{\mathrm{eq}}\right)$, the statistics of assessment were higher than the models that used $\mathrm{Ln}\left(\mathrm{d}_{\mathrm{eq}}\right)$ as a dependent variable, also providing higher precision and less tendency in the estimates.

Figure 4 shows the dispersion of observed and estimated values of $\mathrm{d}_{\mathrm{eq}}$ (a) and the boxplots of residuals (b). Estimates followed the tendency of observed values, given the dispersion of points over line 1:1 (Figure 4a). Values of $\mathrm{d}_{\mathrm{eq}}$ were overestimated in the extreme classes and slightly underestimated in the median classes (Figure 4b).
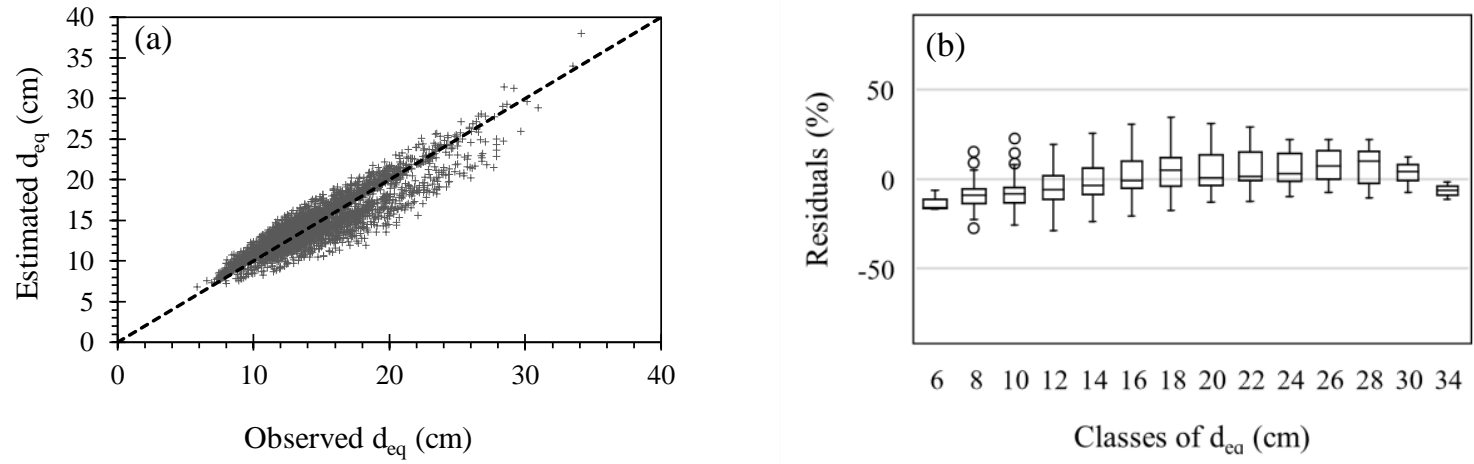

Figure 4. Dispersion of the observed and estimated values (a) and boxplots of the residues (b) for the proposed model for $\mathrm{d}_{\mathrm{eq}}$ for Tachigali vulgaris trees in north Pará, Brazil.

Figura 4. Dispersão dos valores observados e estimados (a) e boxplots dos resíduos (b) para o modelo proposto para $\mathrm{d}_{\mathrm{eq}}$ para árvores de Tachigali vulgaris no norte do Pará.

Once this equation was obtained, the $\mathrm{d}_{\mathrm{eq}}$ of trees of the plots and the respective individual volume were estimated, as well as the volume per plot and per hectare. The paired " $t$ " test was used to verify the compatibility among values per area unit $\left(\mathrm{m}^{3} \mathrm{ha}^{-1}\right)$ obtained through observed and estimated $\mathrm{d}_{\text {eq. }}$. The statistics " $\mathrm{t}$ " was 0.23 ( $\mathrm{p}$ value $=0.83)$. When observing this statistic by age (months), the " $t$ " value was 1.16 ( $\mathrm{p}$-value $=0.30)$.

Although the differences have not been statistically significant, it is interesting to understand their behavior according to initial planting spacings and age. Figure 5 shows the average percentage difference and the respective standard deviations for treatments (a) and age (b). The highest compatibility of estimates of volumetric production occurred for the spacing $3.0 \times 2.5 \mathrm{~m}$ (Figure $5 \mathrm{a}$ ). For the other treatments, small differences occurred, a likely result due to the tendency to increase the number of trunks per tree as the spacing increased, where the average number of trunks was $1.7 ; 1.9 ; 2.1 ; 2.2 ; 2.4 ; 2.3$ for spacings $3.0 \times 1.5 \mathrm{~m} ; 3.0 \times 2.0 \mathrm{~m} ; 3.0 \times 2.5 \mathrm{~m} ; 3.0 \times$ $3.0 \mathrm{~m} ; 3.0 \times 3.5 \mathrm{~m}$; and $3.0 \times 4.0 \mathrm{~m}$, respectively.
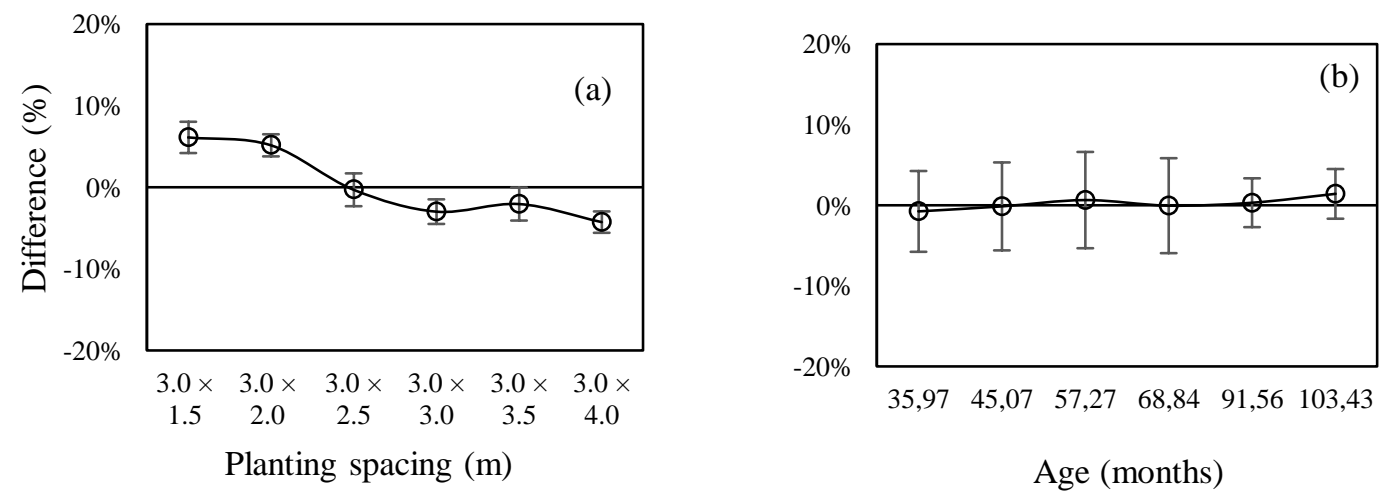

Figure 5. Average percentage difference and standard deviation in volume estimates per unit area obtained by observed and estimated $\mathrm{d}_{\mathrm{eq}}$, by treatment (a) and age (b), for Tachigali vulgaris plantations in northern Pará, Brazil.

Figura 5. Diferença percentual média e desvio padrão nas estimativas de volume por unidade de área obtidos por $\mathrm{d}_{\mathrm{eq}}$ observado e estimado, por tratamento (a) e idade (b), para plantios de Tachigali vulgaris no norte do Pará. 
According to the result of the model identity test, hypothesis $\mathrm{h}_{0(1)}$ was rejected because the estimates of volume obtained by equations adjusted by spacing did not statistically differ from those obtained by a single equation developed for all data. According to the results of statistical adjustment assessment performed, hypothesis $h_{0(2)}$ was not disregarded since the equivalent diameter provided more precise and accurate estimates of volume compared to diameter at breast height. With the results of test " $t$ ", hypothesis $h_{0(3)}$ was not disregarded since the estimates of volume per area unit considering the estimated equivalent diameter did not statistically differ from the respective volumes obtained when considering the observed equivalent diameter.

\section{DISCUSSION}

The lower precision of simple entry models compared to double entry models was predicted. This affirmation has been corroborated by studies such as Thaines et al. (2010), Tonini; Borges (2015) and Correia et al. (2017), who found an expressive increase of precision for volume estimates when using commercial height as independent variable. This result is related to the correlation between tree height and volume, since tree shape is influenced by its height.

Although the model of Stoate has shown a slightly lower $\mathrm{S}_{\mathrm{yx}} \%$, it was found that the equation obtained with the Schumacher-Hall model showed more accurate estimates, in addition to all its regression coefficients being significant. The efficiency of the Schumacher-Hall model is corroborated by other studies performed for different forest species, such as Fernandes et al. (2017), Lanssanova et al. (2018), and Andrade et al. (2019).

Thus, the Schumacher-Hall model was selected to estimate volume of tachi-branco in the different spacings assessed by using the equivalent diameter. In a similar manner, Souza et al. (2016) used the SchumacherHall equation with equivalent diameter as an independent variable, which allowed to precisely estimate total volume with bark of trunks of forest species in the Caatinga (SOUZA et al., 2016).

It is evident the similarity in behavior of the curves of volume estimates in relation to the similarity of tree growth in different spacings. An explanation for this similarity between volumetric estimates obtained by the different equations is the low variability between mean volumes per tree among spacings $(\mathrm{CV}=18.3 \%)$, besides the elevated tree mortality rate in the smaller planting spacings, which varied between 45 and $50 \%$, while in the larger spacings this percentage was close to $15 \%$. For instance, at 9 years, mortality approximated trunk densities, being between 1,618 and 1,354 trunks per hectare in spacings $3.0 \times 1.5 \mathrm{~m}$ and $3.0 \times 4.0 \mathrm{~m}$, respectively.

The species Tachigali vulgaris is susceptible to competition, which consequently intensifies with the increase of planting density. In the last measurements, a relatively expressive amount of natural regeneration was identified in the experiment area including herbaceous plants, bushes, and trees. Since the effect of spacing is directly related to the extent of plant competition for resources such as water, nutrients, and light, the presence of these regenerants could have suppressed the potential difference of production that could occur among spacings if there was not a competitor vegetation other than the tachi-branco trees.

However, Tonini et al. (2018) assessed growth and energetic quality of Tachigali vulgaris wood in different spacings, in Cantá, Roraima. They concluded that the planting spacing had no influence on diametric growth, volumetric production, individual biomass produced in the trunk, and species energetic potential.

Thus, in the current age, spacing had no effect on the individual volume of tachi-branco trees. In this context, a single volumetric equation can be used for all spacings. This equation is based on the Schumacher-Hall model, using the equivalent diameter. For future studies, a specific equation for the species can be developed and studied, to find more precise estimates face to the great commercial potential of tachi-branco for bioenergetic purposes in the Amazon.

\section{CONCLUSION}

- In the studied planting conditions, planting spacing has no influence on the development of independent equations of volume, thus a single equation can be used to obtain volume per tree for Tachigali vulgaris trees.

- By the characteristic of forking of Tachigali vulgaris, it is advantageous to use equivalent diameter in the volumetric equation as a replacement for diameter at breast height per trunk.

- For similar conditions to the studied area, the equation $\mathrm{v}=\mathrm{e}^{\left(-9.164635+1.912123 \operatorname{Ln}\left[d_{\mathrm{eq}}\right]+0.751405 \operatorname{Ln}[h]\right)}$ can be used to estimate the volume of Tachigali vulgaris trees.

- The estimated equivalent diameter via equation had no influence on the estimates of volume per area unit. 


\section{ACKNOWLEDGEMENTS}

Authors would like to thank the financial support from the National Council of Scientific and Technological Development - CNPq (process n³06793/2019-9), Grupo Jari and Embrapa Amazônia Oriental, who were crucial for the development of this research. Also, heartfelt thanks to the Foundation for Support of Research in the State of Minas Gerais - FAPEMIG for granting the scholarship for introduction to scientific research.

\section{REFERENCES}

ANDRADE, V. C. L.; GAMA, R. C.; TERRA, D. L. C. V. Revisão sobre modelos volumétricos empregados em povoamentos florestais brasileiros. Advances in Forestry Science Review, Cuiabá, v.6, n.1, p.561-566, 2019. DOI: $10.34062 /$ afs.v6i1.7313.

CARVAlHO, P. E. R. Tachi-branco. Colombo: Embrapa Florestas, 11p. (Embrapa Florestas. Circular técnica, 111), 2005.

CLIMATE-DATE.ORG. Dados climáticos para cidades mundiais. Disponível em: <https://pt.climatedata.org/america-do-sul/brasil/para/monte-dourado-317503/>. Acesso em: 22/08/2021.

CORREIA, J.; FANTINI, A.; PIAZZA, G. Equações volumétricas e fator de forma e de casca para Florestas Secundárias do litoral de Santa Catarina. Floresta e Ambiente, Seropédica, v.24, 2017. DOI: http://dx.doi.org/10.1590/2179-8087.023715.

DOMBROSKI, J. L. D.; PINTO, J. R. S. Crown Area as a Parameter for Biomass Estimation of Croton sonderianus Müll. Arg. Floresta e Ambiente, Seropédica, v.26, n.4, 2019. DOI: 10.1590/2179-8087.024715.

ELOY, E.; CARON, B. O.; SILVA, D. A.; SCHMIDT, D.; TREVISAN R.; BEHLING, A.; ELLI, E. E. Influência do espaçamento nas características energéticas de espécies arbóreas em plantios de curta rotação. Revista Árvore, Viçosa, v.38, n.3, p.551-559, 2014. DOI: 10.1590/S0100-67622014000300018.

FARIAS, J.; MARIMON, B. S.; SILVA, L. C. R.; PETTER, F. A.; ANDRADE, F. R.; MORANDI, P. S.; MARIMON-JUNIOR, B. H. Survival and growth of native Tachigali vulgaris and exotic Eucaliptus urophylla $\mathrm{x}$ Eucalyptus grandis trees in degrated soils with biochar amendment in southern Amazônia. Forest Ecology and Management, Netherlands, v.368, p.173-182, 2016. DOI: 10.1016/j.foreco.2016.03.022.

FERNANDES, A. M. V.; GAMA, J. R. V; RODE, R.; MELO, L. O. Equações volumétricas para Carapa guianensis Aubl. e Swietenia macrophylla King em sistema silvipastoril na Amazônia. Nativa, Sinop, v.5, n.1, p.73-77, 2017. DOI: 10.5935/2318-7670.v05n01a12.

GAMA, A. T.; CABACINHA, C. D.; MEIRA, M. R.; LEITE, M. V. S. Estimativas Volumétricas y Hipsométricas para el Barbatimão en el Norte de Minas Gerais. Floresta e Ambiente, Seropédica, v.22, n.4, p.483-493, 2015. DOI: 10.1590/2179-8087.090314.

INDÚSTRIA BRASILEIRA DE ÁRVORES - IBÁ: Relatório da Indústria Brasileira de Árvores. Brasília: IBÁ, ano base 2019. 66p. Disponível em: 〈http://www.iba.org/>. Acesso em: 25/10/2020.

LANSSANOVA, L. R.; SILVA, F. A; SCHONS, C. T.; SILVA, A. C. Comparação entre diferentes métodos para estimativa volumétrica de espécies comerciais da Amazônia. BIOFIX Scientific Journal, Curitiba, v.3, n.1, p.109-115, 2018. DOI: 10.5380/biofix.v3i1.57489.

MACHADO, S. A.; CONCEIÇÃO, M. B.; FIGUEIREDO, D. J. Modelagem do volume individual para diferentes idades e regimes de desbaste em plantações de Pinus oocarpa. Ciências Exatas e Naturais, Curitiba, v.4, n.2, p.185-196, 2002.

MOUlin, J. C.; ROCHA, M. F. V.; ARANTES, M. D. C.; BOSCHETTI, W. T. N.; JESUS, M. S. TRUGILHO, P. F. Influência do espaçamento de plantio e irrigação na densidade e na massa seca em espécies de Eucalyptus. Nativa, Sinop, v.5, n.5, p. 367-371, 2017. DOI: 10.5935/2318-7670.v05n05a11.

ORELlanA, B. B. M. A.; VAlE, A. T.; GONÇALEZ, J.; GUEDES, M. C.; ORELlANA, J. B. P.; LIMA, C. M. Produtividade energética da madeira de Tachigali vulgaris por classe diamétrica em plantios experimentais na Amazônia. Nativa, Sinop, v.6, n.especial, p.773-781, 2018. DOI: 10.31413/nativa.v6i0.5130.

PELISSARI, A. L.; LANSSANOVA, L. R.; DRESCHER, R. Modelos volumétricos para Pinus tropicais, em povoamento homogêneo, no Estado de Rondônia. Pesquisa Florestal Brasileira, Colombo, v.31, n.67, p.173181, 2011. DOI: 10.4336/2011.pfb.31.67.173. 
REGAZZI, A. J.; SILVA, C. H. O. Testes para verificar a igualdade de parâmetros e a identidade de modelos de regressão não-linear em dados de experimento com delineamento em blocos casualizados. Revista Ceres, Viçosa, v.57, n.3, p.315-320, 2010. DOI: 10.1590/S0034-737X2010000300005.

ROLIM, S. G.; PIOTTO, D. Silvicultura e Tecnologia de Espécies da Mata Atlântica. Editora Rona. 2018, 160 p.

SILVA, H. F.; RIBEIRO, S. C.; BOTELHO, S. A.; LISKA, G. R.; CIRILLO, M. A. Biomass and carbon in a seasonal semideciduous forest in Minas Gerais. Floresta e Ambiente, Seropédica, v.25, n.1, 2018. DOI: 10.1590/2179-8087.050816.

SILVA, M. O. S.; SILVA, M. G.; BUFALINO, L.; ASSIS, M. R.; GONCALVES, D. A.; TRUGILHO, P. F.; PROTÁSIO, T. P. Variations in productivity and wood properties of Amazonian tachi-branco trees planted at different spacings for bioenergy purposes. Journal of Forestry Research, Ottawa, p.1-14, 2019.

SOUSA, V. G.; BRIENZA JR., S.; BARBOSA, M. G.; MARTORANO, L. G.; SILVA, V. C. Taxi-branco (Tachigali vulgaris L. F. Gomes da Silva \& H. C. Lima): botânica, ecologia e silvicultura. Documentos Embrapa, Belém, 2016.

SOUZA, P. F.; SILVA, J. A.; LUCENA, D. S.; SANTOS, W. S.; HENRIQUES, Í. G. N.; LUCENA, M. F. A.; SOUZA, A. D. Estudos fitossociológicos e dendrométricos em um fragmento de Caatinga, São José de Espinharas - PB. Ciência Florestal, Santa Maria, v.26, n.4, p.1317-1330, 2016.

STAllBAUN, P. H.; BARAÚNA, E. E. P.; MONTEIRO, T. C.; VIEIRA, R. S.; SALES, N. L. P.; OLIVEIRA, L. S. Resistência natural da madeira de Tachigali vulgaris ao fungo xilófago Postia placenta. Pesquisa Florestal Brasileira, Colombo, v.36, n.88, p.459-463, 2016. DOI: 10.4336/2016.pfb.36.88.1231.

THAINES, F.; BRAZ, E. M.; MATTOS, P. P.; THAINES, A. A. R. Equações para a estimativa de volume de madeira para a região da bacia do Rio Ituxi, Lábrea, AM. Pesquisa Florestal Brasileira, Colombo, v.30, n.64, p.283-289, 2010. DOI: 10.4336/2010.pfb.30.64.283.

TONINI, H.; BORGES, R. A. Equação de volume para espécies comerciais em Floresta Ombrófila Densa no sul de Roraima. Pesquisa Florestal Brasileira, Colombo, v.35, n.82, p.111-117, $2015 . \quad$ DOI: https://dx.doi.org/10.4336/2015.pfb.35.82.738.

TONINI, H.; SCHWENGBER, D. R.; MORALES, M. M.; OLIVEIRA, J. M. F. Crescimento e qualidade energética da madeira de Tachigali vulgaris sob diferentes espaçamentos. Pesquisa Florestal Brasileira, Colombo, v.38, p.1-8, 2018. DOI: 10.4336/2018.pfb.38e201801569. 